\title{
Biomonitoring of water genotoxicity in a Conservation Unit in the Sinos River Basin, Southern Brazil, using the Tradescantia micronucleus bioassay
}

\author{
Endres Júnior, D. ${ }^{a}$, Sasamori, $M H .^{a}$, Cassanego, MBB. ${ }^{a, b}$ and Droste, A. ${ }^{a, b *}$ \\ ${ }^{a}$ Laboratório de Biotecnologia Vegetal, Universidade Feevale, Rodovia RS-239, 2755, \\ CEP 93525-075, Novo Hamburgo, RS, Brazil \\ 'Programa de Pós-Graduação em Qualidade Ambiental, Universidade Feevale, Rodovia RS-239, 2755, \\ CEP 93525-075, Novo Hamburgo, RS, Brazil \\ *e-mail: annette@feevale.br
}

Received: May 24, 2013 - Accepted: July 21, 2013 - Distributed: May 31, 2015

(With 3 figures)

\begin{abstract}
The Tradescantia micronucleus (Trad-MCN) bioassay was used to investigate genotoxicity of water bodies in the Parque Municipal Henrique Luís Roessler (PMHLR), a conservation unit in the city of Novo Hamburgo, Southern Brazil, from November 2010 to October 2011. Every month, cuttings with young inflorescences of Tradescantia pallida var. purpurea were exposed for 24 hours to water collected at three sites in the park: (S1) head of the main stream; (S2) head of a secondary stream; (S3) a point past the junction of the two water bodies in which S1 and S2 were located. As a negative control, cuttings were exposed to distilled water for $24 \mathrm{~h}$ every quarter. Micronuclei (MCN) frequency was determined in young tetrads of pollen mother cells and described as MCN/100 tetrads. Rainfall data were also recorded. In nine months at S1 and S2, and in eleven months at S3, micronuclei frequencies were significantly higher than in quarterly controls, in which frequencies varied from 1.19 to 1.62. During sampling, no significant differences were found in $\mathrm{MCN}$ frequencies at S1, which ranged from 2.2 to 3.6. At the other sampling sites, there were significant differences between the months evaluated, and MCN frequencies ranged from 1.3 to 6.5 at $\mathrm{S} 2$ and from 2.3 to 5.2 at S3. There were no associations between rainfall and MCN frequencies at the three sampling sites. Tradescantia pallida var. purpurea confirmed genotoxicity in the water bodies of the PMHLR, even at the head of the streams, which suggests that actions should be promoted to control anthropogenic effects in the streams of this conservation unit.
\end{abstract}

Keywords: pollution, environmental quality, protected areas, watershed, Tradescantia pallida var. purpurea.

\section{Biomonitoramento da genotoxicidade da água em uma Unidade de Conservação na Bacia do Rio dos Sinos, Sul do Brasil, utilizando o bioensaio de micronúcleo em Tradescantia}

\begin{abstract}
Resumo
O bioensaio de micronúcleo em Tradescantia (Trad-MCN) foi utilizado para investigar a genotoxicidade de corpos d'água no Parque Municipal Henrique Luís Roessler (PMHLR), uma Unidade de Conservação no município de Novo Hamburgo, Sul do Brasil, de novembro de 2010 a outubro de 2011. Mensalmente, ramos com inflorescências jovens de Tradescantia pallida var. purpurea foram expostos por 24 horas a amostras de água coletadas em três pontos de cursos d'água no interior do parque: (S1) nascente do principal curso d'água; (S2) nascente de um curso d'agua secundário; (S3) ponto situado após a junção dos corpos d'água em que S1 e S2 estavam localizados. Como controle negativo, ramos foram expostos à água destilada por $24 \mathrm{~h}$, com periodicidade trimestral. Frequências de micronúcleos (MCN) foram determinadas em tétrades jovens de células-mãe de grãos de pólen e expressas como MCN/100 tétrades. Dados de precipitação também foram registrados durante o experimento. Foram observadas frequências de MCN significativamente superiores em nove meses em S1 e S2 e em onze meses em S3 quando comparadas às frequências nos controles trimestrais, que variaram de 1,19 a 1,62. Durante o período de amostragem, não foram encontradas diferenças significativas nas frequências de $\mathrm{MCN}$ em S1, que variaram de 2,2 a 3,6. Nos demais pontos amostrais, houve diferenças significativas entre os meses avaliados para as frequências de MCN, que variaram de 1,3 a 6,5, em $\mathrm{S} 2$, e de 2,3 a 5,2, em S3. Não foi verificada relação entre a pluviosidade e as frequências de MCN observadas nos três pontos amostrais. Tradescantia pallida var. purpurea indicou haver genotoxicidade nos corpos hídricos do PMHLR, inclusive junto às nascentes, indicando a necessidade de ações que visem ao controle do efeito antropogênico sobre a água nesta unidade de conservação.
\end{abstract}

Palavras-chave: poluição, qualidade ambiental, áreas protegidas, bacia hidrográfica, Tradescantia pallida var. purpurea . 


\section{Introduction}

In urban centres, water resources are usually polluted due to the indiscriminate disposal of domestic sewage and industrial effluents, as well as garbage disposal in inadequate sites (Tundisi, 2003; Blume et al., 2010). As pollutants are released, complex and potentially toxic mixtures are formed and accumulated and may later have negative impacts on living organisms (Ohe et al., 2004).

Water bodies in river basins that include large urbanised areas are more susceptible to a set of anthropogenic effects, which contribute to the growing contamination of water ecosystems. The area of the Sinos River Basin, in the eastern region of the state of Rio Grande do Sul, in southern Brazil, has a high demographic density and a disorganised urban and industrial occupation model. The basin covers an area of about $3.800 \mathrm{~km}^{2}$ in 32 municipalities that have a population of about 1.6 million inhabitants, which accounts for about $12 \%$ of the state population, although concentrated in only $1.5 \%$ of its total area (Rio Grande do Sul, 2012). According to the State Foundation of Environmental Protection of the State of Rio Grande do Sul - FEPAM (Rio Grande do Sul, 2013), 90.6\% of the population from this basin is in urban areas, while the rest lives in rural areas.

Municipal parks have an important role in the conservation of biodiversity. Located in urban areas, they are remaining patches of natural habitats and contribute to environmental quality because of their biotic resources, as well as their water and microclimate characteristics (Schmitt and Goetz, 2010). In the Sinos River Basin, the Parque Municipal Henrique Luís Roessler (PMHLR) is the largest fragment of forest in the urban area of the city of Novo Hamburgo. Created in 2007, the park was formally declared a Conservation Unit in 2009, in the category of Relevant Area of Ecological Interest. Springs inside the park are the head of streams that run to the Sinos River watershed (Rosa, 2010).

In Brazil, Federal Law no. 9433/97 instituted the National Policy of Water Resources to legislate about the management of water resources and to ensure that present and future generations will have good quality water for its various uses (Brasil, 1997). According to current legislation, the quality of water bodies is classified according to physical, chemical and bacteriological parameters defined in the CONAMA Resolution no. 357/05 (Brasil, 2005). However, those parameters reflect water quality only at sampling time, and are not capable of providing direct information about negative impacts of complex mixtures of pollutants on living organisms (Isidori et al., 2003). Biomonitoring is an efficient tool to obtain information about water quality because it evaluates biological responses to environmental changes, such as anthropogenic effects (Ma et al., 1994). The genetic damage of water contaminants on living organisms have been investigated with success using plant bioassays (Grisolia and Starling, 2001; Ohe et al., 2004; Merlo et al., 2011).
The Tradescantia micronucleus (Trad-MCN) bioassay, a sensitive test for the evaluation of genotoxicity, is based on small chromatin masses derived from chromosomal breakages or on aneuploidy during meiosis of the pollen mother cells (Ma et al., 1994). Tradescantia pallida (Rose) D.R. Hunt var. purpurea Boom, a wild species that is well adapted to subtropical and tropical climates, has a high sensitivity to genotoxic agents and has been used to monitor water bodies and residual waters of domestic sewage (Umbuzeiro et al., 2007; Mielli et al., 2009; Thewes et al., 2011). In this study, the genotoxicity of water bodies in the PMHLR Conservation Unit was biomonitored for one year using the Trad-MCN bioassay.

\section{Material and Methods}

\subsection{Study area}

This study was conducted in the Parque Municipal Henrique Luís Roessler (PMHLR) (2941'S and 51 $06^{\circ} \mathrm{W}$, alt. $16.4 \mathrm{~m}$ ) in the city of Novo Hamburgo in the Sinos River Basin, in the state of Rio Grande do Sul, southern Brazil. The park is in the urban area of the town and has an area of 54 hectares of fields, wet areas and secondary forests (Rosa, 2010) classified as a semi-deciduous seasonal lowland forest (Teixeira et al., 1986).

The springs inside the park contribute to form the Vila Kunz stream, which is about $5 \mathrm{~km}$ long, runs through the urban area of the town and flows into the Sinos watershed (Rosa, 2010). Three sampling sites were selected in the park (Figure 1). Sampling site 1 (S1) (2940'50.4'"S and $51^{\circ} 06$ '29.3"W) is the main head of the longest stream in the park, which runs into another water body that originates at another stream head, in which site 2 (S2) is located (29 41'04.0"S and 51 06'34.5'W). Sampling site 3 (S3) $\left(29^{\circ} 41^{\prime} 23.4^{\prime \prime} \mathrm{S}\right.$ and $51^{\circ} 06^{\prime} 31.1$ ' $\left.\mathrm{W}\right)$ is a point past the junction of the water bodies in which S1 and S2 were located, at $990 \mathrm{~m}$ from S1 and $430 \mathrm{~m}$ from S2. S1 is in an area with large trees and native plants. S2 is close to a trail used by pedestrians, and its vegetation includes native and exotic tree species. S3 is covered by vegetation, but is environmentally impacted by garbage disposal. In the park area, there are several outflow drains for animal and domestic sewage collected in the surrounding areas (Leuck, 2010).

The climate in the state of Rio Grande do Sul is humid, with regularly distributed rainfall along the year (Buriol et al., 2007). Data on rainfall in the study area were supplied by the closest meteorological station, located in the municipality of Campo Bom $\left(29^{\circ} 41^{\prime} \mathrm{S}\right.$ and $51^{\circ} 03^{\prime} \mathrm{W}$, alt. $25.8 \mathrm{~m})$.

\subsection{Water sampling}

Samples of water from the three sampling sites were collected every month from November 2010 to October 2011. The water samples were stored in plastic containers and taken to the laboratory for genotoxicity tests. Water collection and transportation followed the recommendations of the Brazilian Association of Technical Norms (ABNT, 1987) 
and the Standard Methods for the Examination of Water and Wastewater (APHA, 2005).

\subsection{Trad-MCN bioassay}

Samples of Tradescantia pallida var. purpurea were grown in pots $(37 \mathrm{~cm} \times 20 \mathrm{~cm} \times 20 \mathrm{~cm})$ containing $4 \mathrm{~kg}$ of commercial soil from the same batch and placed in a non-polluted area of the university. The plants were watered three times a week. Monthly, $100 \mathrm{~mL}$ of an N-P-K fertilizer solution (10-10-10, w/w/w) was applied. Plant exposure, inflorescence fixation and storage, slide preparation and data analysis followed the protocol described by Costa and Droste (2012). Cuttings collected from the plant stocks bearing young inflorescences were divided into groups of 15 to 20 and exposed to water samples from each sampling site for $24 \mathrm{~h}$. Every three months, a negative control was prepared using the same method, but replacing stream water with distilled water. The plants were exposed in the laboratory at $26^{\circ} \mathrm{C}$ under natural light. The inflorescences were fixed in $3: 1(\mathrm{v} / \mathrm{v})$ ethanol/acetic acid for $24 \mathrm{~h}$ and stored in $70 \%$ ethanol under refrigeration. One bud in each inflorescence was dissected, and the anthers were squashed in $1 \%$ acetocarmine stain on a slide. Only preparations with early tetrads were included in the analysis. Seven slides were prepared for each sample, and the number of MCN in a random set of 300 tetrads per slide was scored under $400 \times$ magnification (Olympus CX4 microscope). MCN frequencies were calculated by dividing the total number of micronuclei by the total number of tetrads scored, and the results were expressed as MCN/100 tetrads (Thewes et al., 2011).

\subsection{Statistical analysis}

The Trad-MCN bioassay data were analysed using SPSS 20 for Windows. Data were described as means \pm standard deviations (SD). The normal distribution of variables was evaluated using the Shapiro-Wilk test. ANOVA, followed by the Tukey test, was used to analyze the statistical differences in MCN frequencies at each sampling site along time. The level of significance was set at $5 \%$. The Student $t$ test was used to compare the MCN frequency of each sample (sampling site and month) and the quarterly control, at a level of significance of $5 \%$. The Pearson correlation coefficient was used to analyse the association of MCN frequency at sampling sites and accumulated rainfall in the three previous days and on the day that Tradescantia pallida var. purpurea was exposed to water samples.

\section{Results}

Genotoxicity was confirmed in the water courses of PMHLR during the sampling period. S1 had MCN frequencies significantly higher than the quarterly controls in nine months, except in January $(t=2.310, p=0.056)$, March $(\mathrm{t}=2.145, \mathrm{p}=0.062)$ and September $(\mathrm{t}=1.645, \mathrm{p}=0.148)$ of 2011 (Figure 2a). MCN frequencies at S2 were also significantly higher than quarterly controls, except in January $(t=2.039, p=0.087)$, February $(t=0.452, p=0.659)$ and October $(\mathrm{t}=0.413, \mathrm{p}=0.691)$ of 2011 (Figure 2b). At S3, there were significant differences between $\mathrm{MCN}$ frequency and the quarterly controls in all sampling months, except in June of $2011(\mathrm{t}=1.449, \mathrm{p}=0.173)$ (Figure 2c).

In the 12 months, no significant differences were found in $\mathrm{MCN}$ formation at $\mathrm{S} 1(\mathrm{~F}=1.129, \mathrm{p}=0.352)$, which ranged

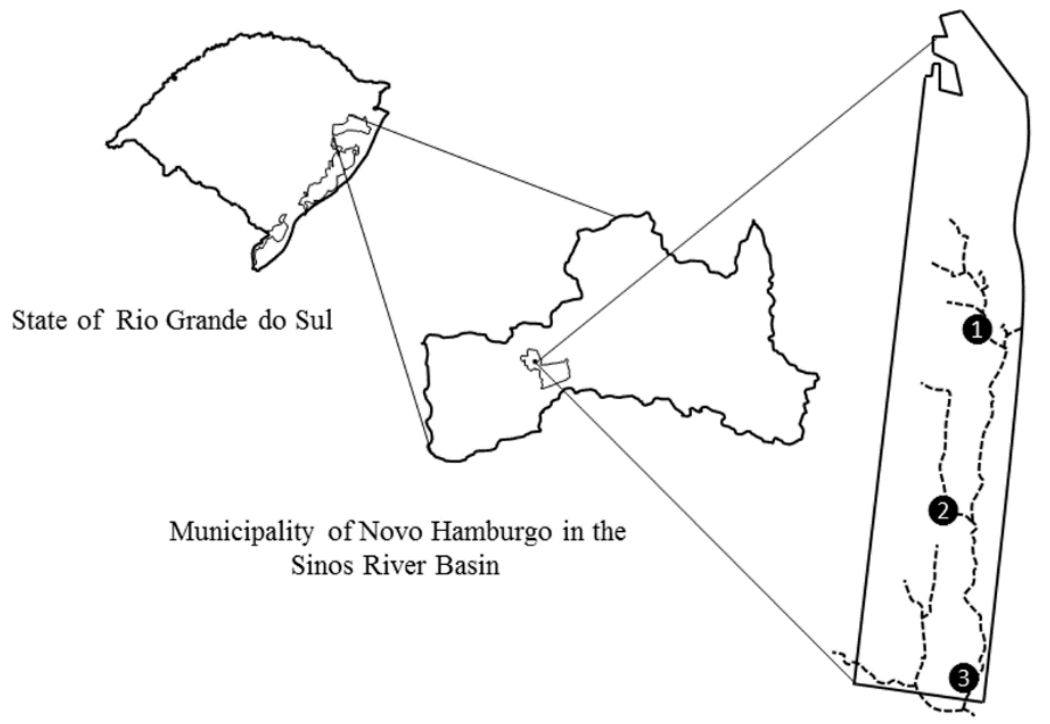

Conservation Unit

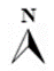

$0 \quad 80160 \quad 320 \mathrm{~m}$

Figure 1. Location of the sampling sites in the Henrique Luís Roessler Municipal Park, a conservation unit in the city of Novo Hamburgo, in the state of Rio Grande do Sul, Brazil. 
from 2.24 in May to 3.62 in December (Figure 2a). At S2, there were markedly significant differences between the months evaluated $(\mathrm{F}=4.434, \mathrm{p}<0.001)$ : the highest value was 6.48 in August, which differed significantly from the frequencies observed in the other months, excepting November, January and September (Figure 2b). S3 also showed significant differences between sampling months
$(\mathrm{F}=2.685, \mathrm{p}=0.006)$. Water in August presented greater genotoxicity, with 5.24 MCN, significantly different from MCN frequencies observed in December, February, May, June, July and October (Figure 2c).

Rainfall accumulated in the three days before exposure and on exposure day is shown in Figure 3. The highest amount of accumulated rainfall, $79.1 \mathrm{~mm}$, was found in
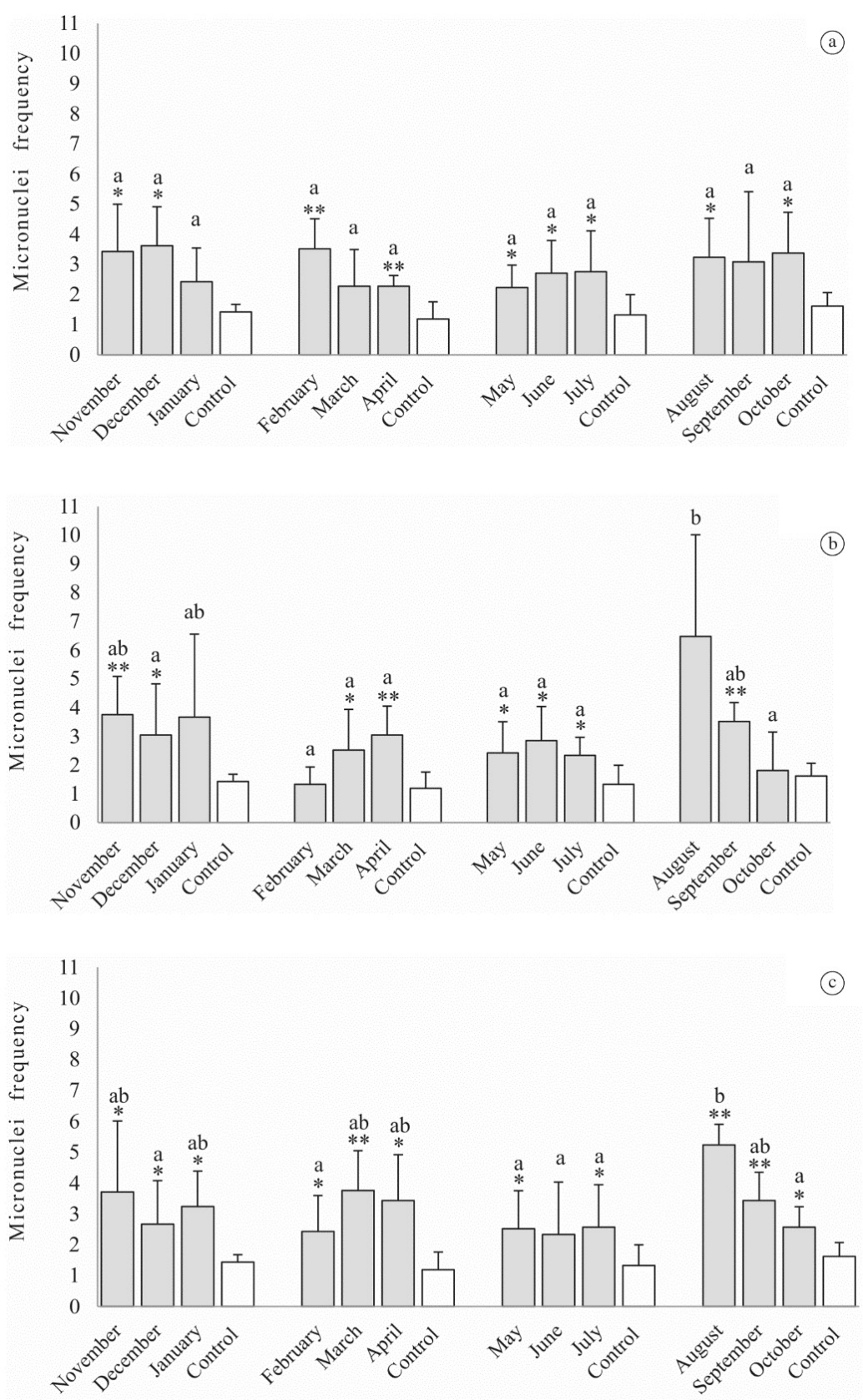

Figure 2. Micronuclei (MCN) frequency in cuttings of Tradescantia pallida var. purpurea exposed to water collected at three sites of streams in Henrique Luís Roessler Municipal Park in Novo Hamburgo, Brazil. (a) S1 = sampling site at head of main stream; (b) S2 = sampling site at head of secondary water course; and (c) S3 = sampling site past junction of streams in which S1 and S2 were located. Columns show means \pm standard deviations. Different letters indicate significant differences between months considering samples from each sampling site according to Tukey test $(\mathrm{p}=0.05)$. Asterisks indicate significant $(*)$ and highly significant $(* *)$ differences from quarterly negative controls (Student $t$ test). 


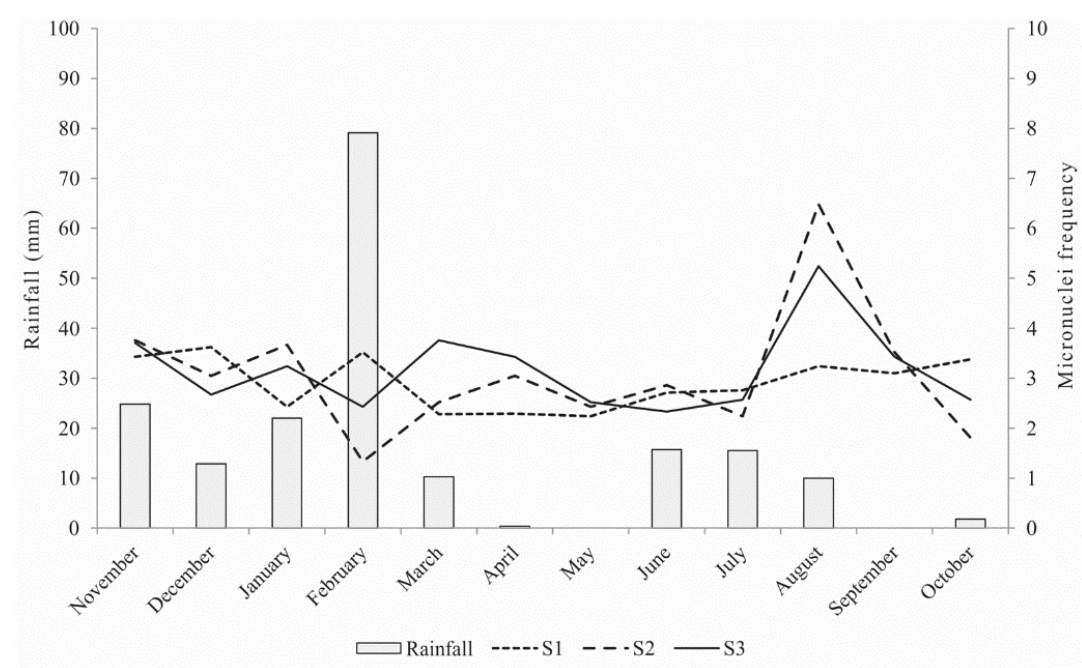

Figure 3. Micronuclei frequency in Tradescantia pallida var. purpurea plants exposed to sampling sites and accumulated rainfall three days before and on the day of plant exposure in the study area.

February. In May and September, there was no rainfall immediately before collection. There was no association between rainfall and $\mathrm{MCN}$ frequency at $\mathrm{S} 1(\mathrm{r}=0.404$, $\mathrm{p}=0.193), \mathrm{S} 2(\mathrm{r}=-0.309, \mathrm{p}=0.329)$ or $\mathrm{S} 3(\mathrm{r}=-0.224, \mathrm{p}=0.485)$.

\section{Discussion}

Micronuclei frequencies at the different sampling sites during the year showed that the Trad-MCN bioassay was capable of clearly demonstrating the genotoxic potential of the water courses in the PMHLR, which should be a warning about the possible harmful effects of water pollutants for living organisms in that environment. Sources of pollution previously recorded in the park, such as the outflow of domestic sewage and the illegal disposal of garbage close to water bodies, have been described as factors that affect the physical and chemical quality of water (Leuck, 2010). However, in this study, we did not identify which chemicals were responsible for genotoxicity.

The combined effect of complex mixtures of pollutants on biological systems has been little studied (Merlo et al., 2011). Water genotoxicity bioassays using Tradescantia, although not used in many studies, have demonstrated that the risks posed by these mixtures have greater magnitude and effects than isolated substances, but are not yet fully known (for review, see Ohe et al., 2004; Misík et al., 2011).

Genotoxic effects of water bodies have also been found in studies with Tradescantia clones in Asia, Central America and Europe. The use of a bioassay with clone 03 of Tradescantia paludosa E.S. Anderson \& Woodson revealed the presence of genotoxicity in different sampling sites in the Lijang River, in China. There were different levels of pollution, resulting mainly from industrial effluents and domestic sewage, and the mean frequencies ranged from 5.2 to 7.0 MCN (Jiang et al., 1999). The same clone 03 was used to evaluate samples of the Hongzhe
Lake, in China, and mean frequencies of 8.2 to $10.9 \mathrm{MCN}$ were found (Yang, 1999). In that study, there was also a high MCN frequency (6.8) in samples of treated water, which the authors used as a control. Treatments such as chlorination, the most widely used method of disinfecting drinking water, may lead to the formation of several mutagenic byproducts (Buschini et al., 2004), which may preclude the use of tap water as a negative control. Clone 4430, a hybrid of Tradescantia hirsutiflora Bush and Tradescantia subacaulis Bush, has been used to evaluate water genotoxicity in a canal that receives effluents from an industrial district in Queretaro, Mexico. Frequencies ranged from 2.5 to $9.0 \mathrm{MCN}$ and were significantly higher than the control frequency, which was 1.5 MCN (Ruiz et al., 1992). In the Panlong River, in the urban area of a town with three million inhabitants in China, frequencies were 4.6 to $5.9 \mathrm{MCN}$ in samples of river water and $2.49 \mathrm{MCN}$ in the distilled water used as a control (Duan et al., 1999). In rivers in Vienna and Salzburg, in Austria, a bioassay using clone 4430 revealed a significant increase in MCN frequency (7.0) in the water of an urban area of Vienna when compared with the other samples from water bodies and drinking water (Steinkellner et al., 1999).

In a more recent study, Tradescantia pallida var. purpurea was successfully used for an in situ evaluation of genotoxicity in the Cristais River, in the metropolitan area of the city of São Paulo, Brazil (Umbuzeiro et al., 2007). After direct exposure of inflorescences to water for $24 \mathrm{~h}$, a frequency of $1.8 \mathrm{MCN}$ was found in a river tributary used as a reference site and compared with another sampling site downstream from a textile plant, in which the frequency was 6.2 $\mathrm{MCN}$. As the water bodies in our study were sampled at the head of the streams and in a conservation unit, the MCN frequencies were relatively significant.

In addition to the fact that the pollution of the water bodies in the PMHLR expose local biodiversity to potentially 
genotoxic effects, it also contributes to the contamination of the main water course, the Sinos River, which lends its name to the basin. For another affluent of the same river, the Estância Velha stream, records showed high concentrations of pollutants and water toxicity to Daphnia similis Claus, Daphnia magna Straus, Ceriodaphnia dubia Richard and Hyalella azteca Saussure (Mitteregger Júnior et al., 2007). Increased levels of several pollutants have been found in water in the lower third of the Sinos River, in the city of Novo Hamburgo (Blume et al., 2010). Studies point to a significant reduction in the reproduction of the microcrustacean Daphnia magna close to the mouth of the Sinos River (Feiden and Terra, 2009), as well as genotoxicity to fish in several sampling sites along the river (Scalon et al., 2010).

The findings show the value of using Tradescantia pallida var. purpurea as an indicative parameter that is sensitive to environmental pollution of water streams in the Sinos River Basin. The Trad-MCN bioassay revealed the presence of water genotoxicity even at the head of the streams. In part, these results are related to the cell cycle stage of the biomonitor since meiotic cells are pointed as presenting higher sensitivity than mitotic cells to mutagenic agents (Sax and Edmonds, 1933; Ma, 1982). MCN frequency variations along time draw attention to the importance of monitoring at various time points throughout the year. Although the Trad-MCN bioassay may be sensitive to environmental variables, as discussed in studies about the genotoxicity of atmospheric air (Savóia et al., 2009; Costa and Droste, 2012) and of wastewater treatment plants (Thewes et al., 2011), MCN frequency variations in the present study were not associated with rainfall. The influence of rain on the genotoxic potential of water bodies has to be investigated more extensively, since there are records of lower MCN frequencies in Tradescantia pallida var. purpurea exposed to sewage of wastewater treatment plants (Thewes et al., 2011) and in Allium cepa exposed to water from the Sinos River, Brazil (Oliveira et al., 2012) after periods of precipitation.

The presence of domestic sewage in the PMHLR waters and the lack of treatment for most of the domestic effluents in the region indicate the need to promote actions to reverse the anthropogenic effects in water bodies of this conservation unit.

\section{Acknowledgements}

The authors wish to thank: the Universidade Feevale for the use of the laboratory and financial support; the Fundação de Amparo à Pesquisa no Rio Grande do Sul (FAPERGS) for the scholarship awarded to D. Endres Júnior; the Conselho Nacional de Desenvolvimento Científico e Tecnológico (CNPq) for the scholarship awarded to M. H. Sasamori, and the Coordenação de Aperfeiçoamento de Pessoal de Nivel Superior (CAPES) for the doctorate grant awarded to M. B. B. Cassanego.

\section{References}

American Public Health Association - APHA, 2005. Standard methods for the examination of water and wastewater. 21th ed. Washington: APHA/AWWA/WPCF. $1220 \mathrm{p}$.

Associação Brasileira de Normas Técnicas - ABNT, 1987. ABNT NBR 9898: 1987: Preservação e técnicas de amostragem de efluentes líquidos e corpos receptores. Rio de Janeiro: ABNT. 22 p.

BLUME, KK., MACEDO, JC., MENEGUZZI, A., SILVA, LB., QUEVEDO, DM. and RODRIGUES, MAS., 2010. Water quality assessment of the Sinos River, Southern Brazil. Brazilian Journal of Biology $=$ Revista Brasileira de Biologia, vol. 70, supplement 4, p. 1185-1193. http://dx.doi.org/10.1590/S151969842010000600008. PMid:21225160.

Brasil, 1997. Lei Federal $n^{\circ}$ 9.433, de 8 de janeiro de 1997. Institui a política nacional de recursos hídricos. Diário Oficial

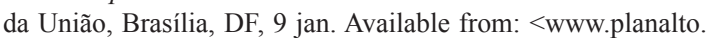
gov.br/CCivil_03/Leis/L9433.htm>. Access in: 02 Jul. 2012.

Brasil. Conselho Nacional do Meio Ambiente - CONAMA, 2005. Resolução $n^{\circ} 357 / 2005$. Dispõe sobre a classificação dos corpos de água e diretrizes ambientais para o seu enquadramento, bem como estabelece as condições e padrões de lançamento de efluentes, e dá outras providências. Diário Oficial da União, Brasília, DF, 18 mar.

BURIOL, GA., ESTEFANEL, V., CHAGAS, AC. and EBERHARDT, D., 2007. Clima e vegetação natural do Estado do Rio Grande Do Sul segundo o diagrama climático de Walter e Lieth. Ciência Florestal, vol. 17, no. 2, p. 91-100.

BUSCHINI, A., CARBONI, P., FRIGERIO, S., FURLINI, M., MARABINI, L., MONARCA, S., POLI, P., RADICE, S. and ROSSI, C., 2004. Genotoxicity and cytotoxicity assessment in lake drinking water produced in a treatment plant. Mutagenesis, vol. 19, no. 5, p. 341-347. http://dx.doi.org/10.1093/mutage/ geh040. PMid:15388805.

COSTA, GM. and DROSTE, A., 2012. Genotoxicity on Tradescantia pallida var. purpurea plants exposed to urban and rural environments in the metropolitan area of Porto Alegre, southern Brazil. Brazilian Journal of Biology $=$ Revista Brasileira de Biologia, vol. 72, no. 4, p. 801-806. http://dx.doi.org/10.1590/ S1519-69842012000500004. PMid:23295507.

DUAN, CQ., HU, B., WANG, ZH., WEN, CH., YAN, SQ., JIANG, XH., WANG, DK., LI, Q. and LIANG, XF., 1999. Tradescantia bioassays for the determination of genotoxicity of water in the Panlong River, Kunming, People's Republic of China. Mutation Research, vol. 426, no. 2, p. 127-131. http://dx.doi.org/10.1016/ S0027-5107(99)00054-8. PMid:10350584.

FEIDEN, IR. and TERRA, NR., 2009. Ecotoxicological evaluation of sediment from a river contaminated by industrial effluents, Sinos River (Rio Grande do Sul, Brazil) using Daphnia magna (Straus, 1820). Acta Limnologica Brasiliensia, vol. 21, no. 4, p. 441-450.

GRISOLIA, CK. and STARLING, FLRM., 2001. Micronuclei monitoring of fishes from Lake Paranoá, under influence of sewage treatment plant discharges. Mutation Research, vol. 491, p. 39-44.

ISIDORI, M., FERRARA, M., LAVORGNA, M., NARDELLI, A. and PARRELLA, A., 2003. In situ monitoring of urban air in Southern Italy with the Tradescantia micronucleus bioassay and semipermeable membrane devices (SPMDs). Chemosphere, vol. 52, no. 1, p. 121-126. http://dx.doi.org/10.1016/S00456535(03)00183-8. PMid:12729694. 
JIANG, YG., YU, ZD., LIU, GZ., CHEN, RZ. and PENG, GY., 1999. Genetoxicity of water samples from the scenic Lijang river in the Guilin area, China, evaluated by Tradescantia bioassays. Mutation Research, vol. 426, no. 2, p. 137-141. http://dx.doi. org/10.1016/S0027-5107(99)00056-1. PMid:10350586.

LEUCK, SM., 2010. Monitoramento e classificação das águas do Parque Municipal Henrique Luís Roessler de Novo Hamburgo. Novo Hamburgo: Universidade Feevale, 85 p. Trabalho de Conclusão de Curso de Graduação.

MA, TH., 1982. Tradescantia cytogenetic tests (root-tip mitosis, pollen mitosis, pollen mother-cell meiosis). Mutation Research, vol. 99, no. 3, p. 293-302. http://dx.doi.org/10.1016/01651110(82)90047-1. PMid:7177155.

MA, TH., CABRERA, GL., CHEN, R., GILL, BS., SANDHU, SS., VANDENBERG, AL. and SALAMONE, MF., 1994. Tradescantia micronucleus bioassay. Mutation Research, vol. 310, no. 2, p. 221-230. http://dx.doi.org/10.1016/0027-5107(94)90115-5. PMid:7523893.

MERlo, C., ABRIL, A., AMÉ, MV., ARGÜEllo, GA., CARRERAS, HA., CHIAPPERO, MS., HUED, AC., WANNAZ, E., GALANTI, LN., MONFERRÁN, MV., GONZÁLEZ, CM. and SOLÍS, VM., 2011. Integral assessment of pollution in the Suquía River (Córdoba, Argentina) as a contribution to lotic ecosystem restoration programs. The Science of the Total Environment, vol. 409, no. 23, p. 5034-5045. http://dx.doi.org/10.1016/j. scitotenv.2011.08.037. PMid:21925711.

MIELLI, AC., MATTA, MEM., NERSESYAN, A., SALDIVA, PHN. and UMBUZEIRO, GA., 2009. Evaluation of the genotoxicity of treated urban sludge in the Tradescantia micronucleus assay. Mutation Research, vol. 672, no. 1, p. 51-54. http://dx.doi. org/10.1016/j.mrgentox.2008.09.007. PMid:18940264.

MISÍK, M., MA, TH., NERSESYAN, A., MONARCA, S., KIM, JK. and KNASMUELLER, S., 2011. Micronucleus assays with Tradescantia pollen tetrads: an update. Mutagenesis, vol. 26, no. 1, p. 215-221. http://dx.doi.org/10.1093/mutage/geq080. PMid:21164205.

MITTEREGGER JÚNIOR, H., SILVA, J., ARENZON, A., PORTELA, CS., FERREIRA, ICFS. and HENRIQUES, JAP., 2007. Evaluation of genotoxicity and toxicity of water and sediment samples from a Brazilian stream influenced by tannery industries. Chemosphere, vol. 67, no. 6, p. 1211-1217. http:// dx.doi.org/10.1016/j.chemosphere.2006.10.048. PMid:17157352.

OHE, T., WATANABE, T. and WAKABAYASHI, K., 2004. Mutagens in surface waters: a review. Mutation Research, vol. 567, no. 2-3, p. 109-149. http://dx.doi.org/10.1016/j.mrrev.2004.08.003. PMid:15572284.

OLIVEIRA, JPW., SANTOS, RN., PIBERNAT, CC. and BOEIRA, JM., 2012. Genotoxicidade e Análises Físico-Químicas das águas do Rio dos Sinos (RS) usando Allium cepa e Eichhornia crassipes como bioindicadores. BBR - Biochemistry and Biotechnology Reports, vol. 1, no. 1, p. 15-22. http://dx.doi.org/10.5433/2316$5200.2012 \mathrm{v} 1 \mathrm{n} 1 \mathrm{p} 15$.

Rio Grande do Sul. Fundação Estadual de Planejamento Metropolitano e Regional do Estado do Rio Grande do Sul METROPLAN, 2012. Fundação Estadual de Planejamento Metropolitano e Regional do Estado do Rio Grande do Sul. METROPLAN. Available from: $<$ http://www.metroplan.rs.gov. br/>. Access in: 03 Sep. 2012.

Rio Grande do Sul. Fundação Estadual de Proteção Ambiental Henrique Luiz Roessler - RS - FEPAM, 2013. Qualidade ambiental - região hidrográfica do Guaíba. FEPAM. Available from: <http://www.fepam.rs.gov.br/qualidade/qualidade_sinos/ sinos.asp >. Access in: 05 May. 2013.

ROSA, NA., 2010. Plano de manejo-Parque Municipal Henrique Luís Roessler - Parcão. Novo Hamburgo: Prefeitura Municipal de Novo Hamburgo. 846 p.

RUIZ, EF., RABAGO, VME., LECONA, SU., PEREZ, AB. and MA, TH., 1992. Tradescantia-micronucleus (Trad-MCN) bioassay on clastogenicity of wastewater and in situ monitoring. Mutation Research, vol. 270, p. 45-51.

SAVÓIA, EJ., DOMINGOS, M., GUIMARÃES, ET., BRUMATI, F. and SALDIVA, PH., 2009. Biomonitoring genotoxic risks under the urban weather conditions and polluted atmosphere in Santo André, SP, Brazil, through Trad-MCN bioassay. Ecotoxicology and Environmental Safety, vol. 72, no. 1, p. 255-260. http://dx.doi. org/10.1016/j.ecoenv.2008.03.019. PMid:18571723.

SAX, K. and EDMONDS, HW., 1933. Development of the male gametophyte in Tradescantia. Botanical Gazette, vol. 95, no. 1, p. 156-163. http://dx.doi.org/10.1086/334371.

SCALON, MCS., RECHENMACHER, C., SIEBEL, AM., KAYSER, ML., RODRIGUES, MT., MALUF, SW., RODRIGUES, MAS. and SILVA, LB., 2010. Evaluation of Sinos River water genotoxicity using the comet assay in fish. Brazilian Journal of Biology $=$ Revista Brasileira de Biologia, vol. 70, supplement 4, p. 1217-1222. http://dx.doi.org/10.1590/S1519-69842010000600011. PMid:21225163.

SCHMITT, JL. and GOETZ, MNB., 2010. Species richness of fern and lycophyte in an urban park in the Rio dos Sinos basin, Southern Brazil. Brazilian Journal of Biology $=$ Revista Brasileira de Biologia, vol. 70, supplement 4, p. 1161-1167. http://dx.doi. org/10.1590/S1519-69842010000600005. PMid:21225157.

STEINKELLNER, H., KASSIE, F. and KNASMÜLLER, S., 1999. Tradescantia-micronucleus assay for the assessment of the clastogenicity of Austrian water. Mutation Research, vol. 426, no. 2, p. 113-116. http://dx.doi.org/10.1016/S0027-5107(99)00051-2. PMid:10350581.

TEIXEIRA, MB., COURA NETO, AB., PASTORE, U. and RANGEL FILHO, ALR., 1986. Vegetação. In: Instituto Brasileiro de Geografia e Estatística - IBGE. Levantamento de recursos naturais. Rio de Janeiro: IBGE, vol. 33, p. 541-620.

THEWES, MR., ENDRES JUNIOR, D. and DROSTE, A., 2011. Genotoxicity biomonitoring of sewage in two municipal wastewater treatment plants using the Tradescantia pallida var. purpurea bioassay. Genetics and Molecular Biology, vol. 34, no. 4, p. 689-693. http://dx.doi.org/10.1590/S1415-47572011005000055. PMid:22215975.

TUNDISI, JG., 2003. Recursos hídricos. MultiCiência, vol. 1, p. $1-15$.

UMBUZEIRO, GA., COIMBRÃO, CA., KUMMROW, F., LOBO, DJA. and SALDIVA, PHN., 2007. Mutagenic activity assessment of Cristais River, São Paulo, Brazil, using the blue rayon/ Salmonella microsome and the Tradescantia pallida micronuclei assays. Journal of the Brazilian Society of Ecotoxicology, vol. 2, no. 2, p. 163-171. http://dx.doi.org/10.5132/jbse.2007.02.009.

YANG, G., 1999. Tradescantia-micronucleus assay on the water quality of lake Hongzhe in Jiangsu Province, China. Mutation Research, vol. 426, no. 2, p. 155-157. http://dx.doi.org/10.1016/ S0027-5107(99)00060-3. PMid:10350590. 